DOI 10.31718/2077-1096.20.4.133

UDC: [616-099-02:543.272.455]-092.9-07:616.15- 078: [577.175.823:577.112.387].088.6

Kolisnyk I.L.

\title{
SUBTOXIC EFFECTS OF SODIUM FLUORIDE ON THE ULTRASTRUCTURE OF PITUITARY GLAND IN RATS
}

Kharkiv Medical Academy of Postgraduate Education

The study aimed at investigating the morphofunctional state of the pituitary gland in white rats under the subtoxic exposure to sodium fluoride. Mature male rats $(N=17)$, weighing $130-150 \mathrm{~g}$, were intragastrically administered with aqueous solutions of sodium fluoride in a dose of 1/10 LD50 ranged from $20 \mathrm{mg} / \mathrm{kg}$ of body weight. The duration of the subacute experiment was 60 days. To assess the morphological rearrangement at the subcellular level of organization of the pituitary gland, electron microscopy was performed. The microscopic study revealed changes in the submicroscopic architecture resulted from dystrophic processes caused by the subtoxic exposure to sodium fluoride. Prolonged sodium fluoride intoxication led to a number of changes in the ultrastructure of the pituitary gland, manifested by the development of intracellular oedema, swelling of mitochondria, changes in the density of their matrix, partial reduction and loss of cristae, vacuolization and expansion of the cisterns of the granular endoplasmic reticulum, an increase in the number of primary lysosomes, in the redistribution of chromatin nucleus and a decrease in the number of ribosomes and glycogen granules. Hemocapillaries showed oedema of endothelial cells, uneven thickening of the basement membrane, vasodilatation with the development of stasis and sludge of erythrocytes. As in the vessels of the hypothalamus, the presence of fibrin and a significant number of platelets has been found. These changes indicate a disruption of bioenergetics associated with the mitochondrial apparatus and the development of hypoxic processes, which lead to a decrease in the activity of redox reactions occurring at the level of intracellular membranes and organelles.

Key words: sodium fluoride, brain, pituitary gland, electron microscopy, ultrastructure, intoxication.

The study was conducted in accordance with the plan for scientific research work of Kharkov Medical Academy of Postgraduate Education of the Ministry of Public Health of Ukraine and is a fragment of the research project of the Department of Clinical Pathophysiology, Topographic Anatomy and Operative Surgery «Pathophysiological mechanisms of action of radiotoxins on the body and the principles of early diagnosis and correction» (state registration number 0117U000589, 2017-2021).

\section{Introduction}

Fluorine compounds are widespread in nature and also known as industrial pollutants. In a free state, fluorine does not exist in nature, but it forms inorganic and organic complex compounds, fluorides, the content of which in the Earth's crust makes up approximately $0.06-0.09 \%$. It is known that low concentrations of fluoride are necessary for normal growth and development of the body. However, with excessive intake of the chemical element, significant dysfunctions of vital organs, cell damage and necrosis occur [1]. The effect of fluoride ions as chemical agents is directed at metabolism, which imbalance manifests in functional and structural changes. Damaging factors result from several pathogenetic mechanisms including the disruption of the energy supply of the processes occurring in the cell and damage to membrane structures and enzyme systems of the cell [2].

The study of the mechanisms of the damaging effect caused by sodium fluoride demonstrates that during the intoxication, the products of their metabolism activate a chain of free radical processes leading to oxidative stress and thus damaging cellular structures. At the same time, the most of the experimental studies presenting the extreme effects of the compound on the body, both in humans and animals, focus on elucidating the mechanisms of the development of oxidative stress and the nature of changes in the ratio between the lipid peroxidation and antioxidant system, while morphological studies are still scanty. The aim of this research was to reveal the peculiarities of the morphofunctional state of the pituitary gland in rats at the ultramicroscopic level following the subtoxic exposure to sodium fluoride.

\section{Material and methods of the research}

The experimental study was conducted on 17 laboratory white male mature rats weighing 130-150 g, aged 3 months. The animals were divided into 2 groups, experimental and control. The experimental group consisted of the rats, which were given intragastrical injections with an aqueous solution of sodium fluoride in a dose of $1 / 10$ LD50 ranged from $20 \mathrm{mg} / \mathrm{kg}$ of animal body weight daily. The control group included intact rats kept under standard vivarium conditions and received the same amount of pure water during the period of the experiment. The duration of the subacute experiment was 60 days followed with the animal decapitation. When working with animals, we were guided by the requirements of the "European Convention for the Protection of Vertebrate Animals used in Experiments and Other Scientific Purposes" (Strasbourg, 1986), Law of Ukraine No. 3447-IV of February 21, 2006 "On the Protection of Animals from Cruelty."

To study the pituitary gland of rats with an assessment of its morphological rearrangement at the ultrastructural level of organization, electron microscopy was performed. Samples of the pituitary tissues were fixed in a $2.5 \%$ solution of glutaraldehyde, in $0.1 \mathrm{M}$ phosphate buffer $\mathrm{pH} 7.2$ and in $1 \%$ osmium tetroxide fixation by G. E. Palade. After dehydration in solutions of increasing concentration of ethanol and absolute acetone, the blocks were embedded into a mixture of epon-araldite resins. Semithin sections of 1-2 $\mu \mathrm{m}$ were cut by ultramicrotome, then stained with methylene blue and studied at the lightoptical level. The ultrathin sections were contrasted with 
uranium and lead citrate by Reynolds. Then they were examined under an electron microscope at an accelerating voltage of $75 \mathrm{kV}$.

\section{Research results and their discussion}

The ultrastructure of the cells of the central links of the neuroendocrine system is characterized by signs of their decreased functional activity. In the hypothalamus, both in "light" and "dark" neurocytes, the ultrastructure of the nuclei is the most significantly altered.

In the pituitary gland, most of the "light" neurocytes are characterized by a typical ultrastructure. In individual "dark" neurocytes, all the main organelles are altered (nucleus, nucleolus, cytoplasm). The nuclei of such cells are enlarged, deformed, and often occupy most of the cytoplasm. Small clumps of heterochromatin are distributed evenly throughout the karyoplasm. The karyolemma is convoluted, nuclear pores are well expressed. The nucleoli are large, with clear contours, eccentrically located in the nuclei. The cytoplasm is depleted in organelles. In some neurocytes, condensation of both nuclear chromatin and organelles is seen against the background of an increase in the electron density of the cytoplasm. Such cells shrink and become fragmented, losing their connection with the neuroglia. The nuclei acquire an atypical shape due to deep invaginations formed by the nuclear membrane. The electron-dense nucleoli are large, located eccentrically, have no fibrillar centers, no granular component. In the cytoplasm, typical organelles are unchanged. The electronic density of the neuropil varies due to an increase in the number of neurofibrillary structures in some nerve fibres and lysis in others. It contains single mitochondria, vacuoles and numerous free ribosomes, lysosomes. Lysosomes are variable in size; some form nucleolus-like bodies. The microstructure of the neuropil is preserved. However, discirculatory disorders are expressed in various parts of the hypothalamus and in the adenohypophysis. The wall of blood capillaries becomes wavy in some places, their lumens are significantly expanded. Perivascular oedema, vascular congestion and manifestations of stasis and sludge are quite visible. In the lumen of blood capillaries, in addition to endothelial cells, erythrocytes and pericytes, fibrin and a large number of platelets are detected. The basement membrane is thin; myelin fibres are concentrated around it. The total amount of myelin fibres is reduced in comparison with that in the intact animals.

In the adenohypophysis, there is an increase in the number of all types of adenocytes, however, many of them are in the process of degeneration, and some parts of the anterior lobe are being destructed. In the adenohypophysis of the experimental rats, interdependent and interrelated changes in the stroma, structures of the vascular bed and adenocytes are observed. Hemocapillaries demonstrate the oedema of endothelial cells, uneven thickening of the basement membrane, vasodilatation with the development of stasis and sludge of erythrocytes. As in the vessels of the hypothalamus, the presence of fibrin and a significant number of platelets is found out. Secretory granules are concentrated near the capillaries. The intensity of damage to adenocytes is different, including the cells of the same type. Most somatotropes preserve their ultrastructure. Individual cells are characterized by a higher electron density of the nucleus and cytoplasm, in which there is an excessive accumulation and stagnation of secretory granules. Vacuolization of the cytoplasm is characteristic of gonadotropes against the background of the destruction processes of most organelles and their 23-fold decrease.

In degranulating adenocytes, the nuclei are round, light, and enlarged. In the karyoplasm, large nucleoli are distinguished by their size, the presence of lumps of heterochromatin, tightly adjacent to the inner membrane of the nuclear envelope, is noticed. The cytoplasm is vacuolated, having short single cisterns of granular endoplasmic reticulum available for examination; ribosomes are virtually not differentiated, mitochondria are swollen, with weakly marked or destroyed cristae. The density and area occupied by the secretory granules are significantly reduced.

\section{Conclusions}

Exposure of the rats to subacute sodium fluoride intoxication for two months leads to morphological restructuring of the central links of the neuroendocrine system at the subcellular level of organization that point out a depression of their functional state. More significant changes were recorded in thyrotropes and corticotropes. The most pronounced shifts were established immediately after the end of the period of intoxication. In the process of readaptation, changes in the vascular bed and the degree of damage to adenocytes somewhat decrease, but desquamative phenomena persist, signs of a decrease in proliferative, synthetic and secretory activity of cells, which indicate a disruption of the neuroendocrine regulation of adaptation of the body as a result of the toxic effect of sodium fluoride on it.

All the changes described above in the cells of the pituitary gland indicate a disruption of the structure of cell membranes - their rigidity increases, lipid-protein interactions change, which leads to disruption of the functioning of transport and enzyme systems of the cell $[4,5,6]$ One of the important mechanisms of damage to membranes and enzymes is excessive activation of free radical reactions and lipid peroxidation, the intensity of which is regulated by the relationship of factors activating and suppressing (antioxidants) this process $[7,8]$.

\section{References}

1. Alekhina DA, Zhukova AG, Sazontova TG, Alekhina DA, Zhukova AG, Sazontova TG. Nizkaya doza ftora vliyayet na AG, Sazontova TG. Nizkaya doza ftora vliyayet na
svobodnoradikal'noye okisleniye i vnutrikletochnyye zashchitnyye
sistemy serdtsa, legkikh i pecheni [Low dose of fluoride influences sistemy serdtsa, legkikh i pecheni [Low dose of fluoride influences
to free radical oxidation and intracellular protective systems in to free radical oxidation and intracellular protective systems in
heart, lung and liver]. Tekhnologii zhivykh system. 2016; 13(6): 4956. (Russian).

2. Kazarina LN, Samarkina AN, Pursanova AYe. Meditsinskiye aspekty kompleksnoy profilaktiki i lecheniya flyuoroza u detey endemichnogo rayona [Medical aspects of complex prophylaxis and treatment of fluorosis in the case of children living in endemic district]. Meditsinskiy al'manakh Medical almanac. 2015; (3): 172175. (Russian).

3. Zhukova AG, Mikhaylova NN, Yadykina TK, Alekhina DA, Gorokhova LG, Romanenko DV i dr. Eksperimental'nyye issledovaniya vnutrikletochnykh zashchitnykh mekhanizmov pecheni pri razvitii khronicheskoy ftoroplasticheskoy intoksikatsii pecheni pri razvitii khronicheskoy ftoroplasticheskoy intoksikatsii
[Experimental studies of intracellular liver protective mec hanisms in development of chronic fluorine intoxication]. Meditsina truda i promyshlennaya ekologiya. 2016; (5): 2124. (Russian).

4. Akimov OYU, Mishchenko AV, Kostenko VO. Vliyaniye sochetannoy nitratno-ftoridnoy intoksikatsii na narusheniya soyedinitel'noy tkani slizistoy obolochki zheludka krys [Influence of soyedinitel'noy tkani slizistoy obolochki zheludka krys [Influence of combined nitrate and fluoride intoxication on connective tissue disorders in rats gastric mucosa]. Arkhiv Balkanskogo Meditsinskogo Soyuza. 2019; 54(3):11-15. DOI: 10.31688/ABMU.2019.54.3.03. (Russian).

5. Yelinskaya AM, Akimov OYU, Kostenko VO. Rol' transkriptsionnogo faktora AP-1 v razvitii okislitel'nogo i nitrozativnogo stressa $v$ tkanyakh parodonta pri sistemnom vospalitel'nom otvete. [Role of AP-1 transcriptional factor in vospalitel'nent of oxidative and nitrosative stress in periodontal tissues during systemic inflammatory response]. Ukrainskiy 


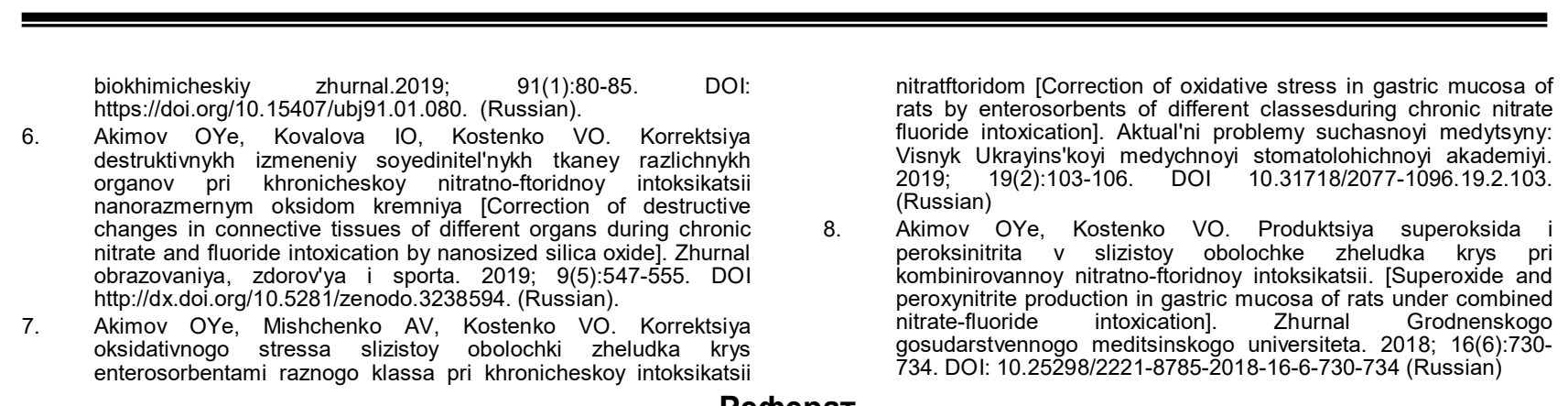

\section{Реферат}

СУБТОКСИЧЕСКОЕ ВОЗДЕЙСТВИЕ ФТОРИДА НАТРИЯ НА УЛЬТРАСТРУКТУРУ ГИПОФИЗА КРЫС

Колесник И.Л.

Ключевые слова: фторид натрия, головной мозг, гипофиз, электронная микроскопия, ультраструктура, интоксикация.

Исследовано морфофункциональное состояние гипофиза белых крыс при субтоксическом действии фрторида натрия. На половозрелых крысах самцах (N=17), массой 130-150 г, которым ежедневно внутрижелудочно вводились водные растворы фрторида натрия дозе 1/10 LD 50 из расчета 20 мг/кг массы животных. Продолжительность подострого опыта составляла 60 суток. Для изучения гипофиза крыс с оценкой его морфологической перестройки на субклеточном уровне организации проводили электронномикроскопическое исследование. Проведенное электронно-микроскопическое исследование ультраструктурной организации гипофиза при воздействии фторида натрия выявило изменения субмикроскопической архитектоники, характерные для развития дистрофических процессов. Длительная интоксикация фрторидом натрия вызывает ряд изменений ультраструктуры гипофиза, выражающихся в развитии внутриклеточного отека, набуханий митохондрий, изменении плотности их матрикса, частичной редукции и потери крист, вакуолизации и расширении цистерн зернистого эндоплазматического ретикулума, увеличении количества первичных лизосом, в перераспределении хроматина ядра и уменьшении числа рибосом и гранул гликогена. В гемокапиллярах выявлен отек эндотелиоцитов, неравномерное утолщение базальной мембраны, вазодилятация с развитием стазов и сладжей эритроцитов. Эти изменения свидетельствуют о нарушении биоэнергетики, связанной с митохондриальным аппаратом и развитием гипоксических процессов, которые ведут к снижению активности окислительно-восстановительных реакций, протекающих на уровне внутриклеточных мембран и органелл.

\section{Рефрерат}

СУБТОКСИЧНИЙ ВПЛИВ ФТОРИДУ НАТРІЮ НА УЛЬТРАСТРУКТУРУ ГІПОФІЗА ЩУРІВ

Колісник І.Л.

Ключові слова: фторид натрію, головний мозок, гіпофріз, електронна мікроскопія, ультраструктура, інтоксикація.

Досліджено морфофункціональний стан гіпофріза білих щурів під впливом субтоксичних дій фрториду натрія. На статевозрілих щурах популяції Вістар ( $N=17)$, масою 130-150 г, яким щодня внутрішньошлунково вводились водні розчини фториду натрію в дозі $1 / 10 L_{50}$ з розрахунку 20 мг / кг маси тварин. Тривалість підгострого досліду становила 60 діб. Для вивчення гіпофізу щурів з оцінкою його морфологічної перебудови на субклітинному рівні організації провели електронномікроскопічне дослідження. Проведене електронно-мікроскопічне дослідження ультраструктурної організації гіпофріза під впливом фториду натрію виявило зміни субмікроскопічної архітектоніки які характерні для розвитку дистрофічних процесів. Тривала інтоксикація фрторидом натрію викликає ряд змін ультраструктури гіпофріза, що виражається в розвитку внутрішньоклітинного набряку, набухання мітохондрій, зміні щільності їх матриксу, часткової редукції і втрати крист, вакуолизації і розширенні цистерн зернистого ендоплазматичного ретикулуму, збільшенні кількості первинних лізосом, в перерозподілі хроматину ядра і зменшенні кількості рибосом і гранул глікогену. У гемокапілярах виявлено набряк ендотеліоцитів, нерівномірне потовщення базальної мембрани, вазодилятація з розвитком стазів і сладж еритроцитів. Ці зміни свідчать про порушення біоенергетики, пов'язаної з мітохондріальним апаратом і розвитком гіпоксичних процесів, які ведуть до зниження активності окислювально-відновних реакцій, що відбуваються на рівні внутрішньоклітинних мембран і органел. В процесі реадаптації відбуваються зміни судинного русла і ступінь ураження аденоцитів, ознаки зниження проліферативної, синтетичної і секреторної активності клітин, які свідчать про порушення нейроендокринної регуляції адаптації організму. 